\title{
DINAMIKA KELOMPOK DAN PENINGKATAN KESEJAHTERAAN: KAJIAN PEMBERDAYAAN KELOMPOK USAHA MERICA MAJU JAYA DI DESA, MOWILA KEC. MOWILA, KAB. KONAWE SELATAN
}

\author{
Sitti Ramdani ${ }^{1}$, Juhaepa ${ }^{2}$, Megawati A. Tawulo ${ }^{3}$ \\ ${ }^{123}$ Universitas Halu Oleo \\ Email: dnyvai0@gmail.com
}

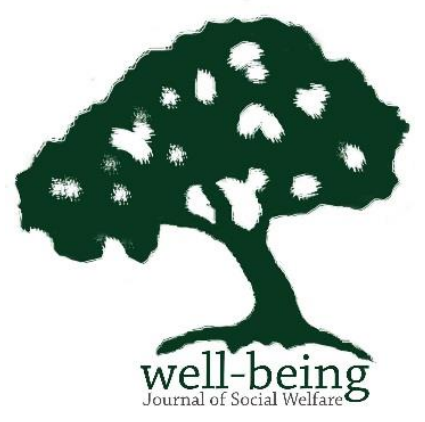

This research was conducted in Mowila Village, Mowila District, Konawe Selatan Regency. This research aims to dig deeper about the real form of efforts to improve the social welfare of farmers through pepper business groups. The method used is purposive sampling. The informants in this study involved pepper farmers as members of the Maju Jaya farmer group with 10 informants. Data collection using observation techniques, indepth interviews, and study of documentation and data analysis was done in a qualitative description. The results of this study indicate that (1) Efforts to Increase Social Welfare of Farmers Through the Merica Business Group, Mowila Village, Mowila District, South Konawe Regency believe: (a) Providing understanding and employment opportunities for disadvantaged people in the world of work. (b) Encouraging and guiding farmers to be able to work together in business in groups. (2) Supporting factors and inhibiting factors of the Mowila Village's advanced pepper business group: (a) Supporting Factors, namely (1) Cooperation (2) Motivation, (3) Being transparent and trusting between related parties. (b) Inhibiting factors, namely (1) Lack of Capital Assistance. (2) limited ingredients to manage pepper. (3) The relationship is not good between members causing boredom that.

Keyword: group dynamics; improvement of welfare; empowerment

\section{PENDAHULUAN}

Sebagai Negara agraris yang berada di wilayah iklim tropis sebagian besar masyarakat di Indonesia berprofesi sebagai petani. Petani menjadi produsen dari sumber makanan yang dikonsumsi oleh banyak masyarakat Indonesia. Di Indonesia sendiri jumlah petani cukup banyak karena didukung dengan kondisi geografis. Problematika yang terjadi saat ini menghampiri petani Indonesia adalah kesiapan dalam bersaing menghadapi MEA (Masyarakat Ekonomi Asia) 2016 serta kebijakan ekspor impor dari pemerintah Indonesia. Petani indonesia perlu memahami betul agar mampu bersaing secara kompetitif dengan negara lain.

Permasalahan kesejahteraan sosial yang berkembang saat ini menunjukkan bahwa ada warga Negara yang belum terpenuhi hak atas kebutuhan dasarnya secara layak karena belum memperoleh pelayanan sosial dari Negara.UU No. 11 Tahun 2009 Tentang Kesejahteraan Sosial bahwa "Kesejahteraan sosial adalah kondisi terpenuhinya kebutuhan material, spiritual, dan sosial warga Negara agar dapat hidup layak dan mampu mengembangkan diri, sehingga dapat melaksanakan fungsi sosial".Akibatnya, masih ada warga negara yang mengalami hambatan pelaksanaan fungsi sosial sehingga tidak dapat menjalani kehidupan secara layak dan bermartabat.Dengan demikian, defenisi ini menekankan bahwa kesejahteraan sosial adalah suatu institusi atau bidang kegiatan yang melibatakan aktivitas terorganisir yang diselenggarakan baik oleh lembaga-lembaga pemerintah maupun swasta yang bertujuan untuk mencegah, mengatasi atau memberikan kontribusi terhadap pemecahan masalah 
sosial, dan peningkatan kualitas hidup individu, kelompok dan masyarakat.

Kelompok tani pada dasarnya adalah organisasi non formal di pedesaan yang ditumbuh kembangkan dari, oleh dan untuk petani. Kelembagaan pertanian adalah norma atau kebiasaan yang terstruktur dan terpola serta dipraktekkan terus menerus untuk memenuhi kebutuhan anggota masyarakat yang terkait erat dengan penghidupan dari bidang pertanian di pedesaan. Dalam kehidupan komunitas petani, posisi dan fungsi kelembagaan petani merupakan bagian pranata sosial yang memfasilitasi interaksi sosial atau social interplay dalam suatu komunitas.Kelembagaan pertani juga memiliki titik strategis (entry point) dalam menggerakkan sistem agribisnis di pedesaan.Untuk itu segala sumberdaya yang ada di pedesaan perlu diarahkan atau diprioritaskan dalam rangka peningkatan profesionalisme dan posisi tawar petani (kelompok tani).Saat ini potret petani dan kelembagaan petani di Indonesia diakui masih belum sebagaimana yang diharapkan.

Berbicara mengenai kelompok tani, ia sifatnya universal sebab hampir disetiap daerah memiliki kelompok tani dengan berbagai macam bentuk pertanian, salah satunya adalah kelompok tani usaha merica. Kelompok usaha tani merica juga ada di daerah Konawe Selatan, Provinsi Sulawesi tenggara khususnya di daerah Mowila. Di Desa Mowila memiliki kelompok usaha merica yang dipelopori oleh salah satu anggota masyakat yang bernama Bapak adnan.Ide ini muncul disebabkan oleh banyaknya petani merica yang berada di Desa Mowila dan belum memliki wadah untuk dijakan sebagai kelompok usaha. Bapak Adnan menganggap penting untuk dibentuknya kelompok usaha merica karena dalam kelompok usaha ini banyak pengetahauan yang bisa diambil melalui pelatihan yang dilakukan oleh pihak dinas pertania Konsel, dan pengetahuan tersebut bisa diterapkan dalam mengelolah perkebunan merica.
Kelompok usaha tani yang berada di Desa Mowila bernama Kelompok Usaha Tani Maju Jaya. Kelompok usaha ini dibentuk sejak tahun 2018 lalu. Semula beranggotakan 15 orang dan seiring perkembanganya jumlahnya terus bertambahingga pada tahun 2019 sudah mencapi 24 orang.

\section{METODE PENELITIAN}

Penelitian ini menggunakan deskriptif kualitatif yakni berusaha mengkaji menelaah dan juga menguraikan data yang akan didapatkan dilapangan yakni upaya peningkatan kesejahteraan sosial petani melalui kelompok usaha merica, penelitian ini menggunakan metode purposive sampling, yaitu pengambilan sumber data dengan pertimbangamn tertentu, misalnya orang terebut dianggap paling tahu tentang informasi yang peneliti harapkan dan yang bersangkutan bersedia dimintai keterangan atau informasi sehubungan dengan penelitian. Informan dalam penelitian ini melibatkan para petani merica sebagai anggota kelompok tani Maju Jaya dengan jumlah 10 orang informan. Data diperoleh melalui wawancara mendalam, observasi dan studi dokumentasi. Analisis data dilakukan secara deskripsi kualitatif yaitu semua sumber data yang diperoleh dilapagan dikumpulkan dan kemudian ditarik kesimpulan berdasarkan jawabanjwaban dari informan yang relevan dengan masalah-masalah dengan penelitian.

\section{HASIL DAN PEMBAHASAN}

\section{Upaya Peningkatan Kesejahteraan Petani Melalui Kelompok Usaha Merica Maju Jaya}

Kelompok Usaha Merica Maju Jaya bagi masyarakat Desa Mowila adalah salah satu bentuk dari pendidikan nonformal yang dibentuk untuk menjembatani masyarakat dalam mendapatkan pengetahuan, keterampilan dan pengalaman melalui suatu kelompok. Kelompok Usaha Merica Maju Jaya dibentuk secara bersama guna meningkatkan kualitas sumber daya manusia agar mampu memasuki dunia 
kerja, dapat meningkatkan kesejahteraan masyarakat Desa Mowila pada umumnya. Program yang dilaksanakan oleh Kelompok Usaha Merica Maju Jaya yaitu memberikan pelatihan pengelolahan merica, dan tabungan.

\section{a. Pelatihan Pengelolahan Merica}

Tujuan dari pemberian pelatihan kepada masyarakat melalui pelatihan pengelolahan merica adalah untuk membangun sumber daya manusia, meningkatkan kemampuan warga dibidang pengetahuan mengelolah merica, agar bakat yang dimiliki menjadi terasa dan dapat menciptakan daya saing dan peluang tenaga kerja.Selain itu, dapat membantu meminimalisir angka kemiskinan, mewujudkan kualitas hidup dan meningkatkan kesejahteraan hidup.

\section{b. Tabungan}

Kegiatan menabung dibentuk oleh pengelola dan anggota. Kegiatan inibertujuan menyiapkan dana untuk masa yang akan datang, seperti kebutuhan hari dalam usaha merica. Tabungan ini bersifat pasif, karena uang yang terkumpul tidakdipinjamkan baik untuk pengelola maupun anggota tapi tabungan tersebut digunakan hanya untuk kebutuhan operasional atau kebutuhan pupuk, alat-alat pertanian yang berhubungan merica, dan lainlain.

\section{Faktor Pendukung Dan Faktor Penghambat Kelompok Usaha Merica}

Untuk mengetahui efektivitas suatu kegiatan atau program kerja maka perlu dilihat bukan hanya dari segi upaya yang telah dilakukan, akan tetapi dapat diketahu pula melalui program kegiatan yang diberikan. Adapun faktor pendukung dan faktor penghambat kesejahteraan sosial Petani melalui Kelompok Usaha Merica Maju Jaya Desa Mowila sebagai berikut:

\section{a. Faktor Pendukung Kelompok Usaha Merica Maju Jaya}

\section{Kerjasama}

Masing-masing pihak harus sadar dan mengakui kemampuan masing-masing antara pengelola, anggota, kepala Desa dan pihak lainnya yang membantu Agar terjalin kerjasama yang mantap dalam suatu kelompok dari masing-masing anggota, sehingga mampu memecahkan masalah yang sedang dihadapi, perlu diperhatikan beberapa hal yang dapat mendukung, antara lain: Masingmasing pihak yang akan kerjasama harus mengerti dan memahami akan masalah yang dihadapi, masing-masing pihak yang bekerjasama perlu berkomunikasi, dan perlu peka terhadap pihak lain dalam arti mengerti kesulitan dan kelemahan orang lain. Semua pihak kelompok harus memberi sesuai dengan kemampuannya, agar semuanya itu dapat berdaya hasil dan berhasil guna, perlu ada pengaturan, yaitu koordinasi yang mantap dan keterbukaan.

\section{Motivasi}

Adanya motivasi yang timbul dari dalam dirinya sendiri dan motivasi dari luar dirinya, motivasi dari luar misalnya keluarga. Keluarga mendorong anggota untuk mengikuti kegiatan mengelolah merica dengan alasan supaya anggota mempunyai pengetahuan dalam kerja. Motivasi sangat penting dalam melaksanakan kegiatan kelompok, karena ketika ada seorang anggota kelompok yang mempunyai sifat malas, maka anggota kelompok lain yang berperan memberikan dorongan, penguatan dan motivasi agar bisa mengembangkan diri guna menciptakan hidup sejahtera dalam lingkungan masyarakat.

\section{Bersifat transparan dan} kepercayaan antara pihak-pihak terkait

Sifat transparan dan saling menjaga kepercayaan dari semua pihak Sifat transparan dan percaya 
diwujudkan oleh pengelola dalam membelajarkan anggota, anggota dalam mengikuti setiap kegiatan, dalam menyediakan modal, dan dalam menjual hasil olahan. Di Kelompok Usaha Merica Maju Jaya sifat tersebut terjalin dengan baik, upaya yang dilakukan untuk mewujudkan sifat transparan dan kepercayaan yaitu breafing dan sharing. Dalam kegiatan breafing dan sharing, baik pengelola dan anggota diberi kesempatan untuk mengungkapkan pendapatnya mengenai hal yang terjadi di Kelompok Usaha Merica Maju Jaya.

b. Faktor Penghambat Kelompok Usaha Merica Maju Jaya

\section{Kurangnya Bantuan Modal}

Salah satu yang menjadikan hambatan Kelompok Usaha Merica Maju Jaya dalam mendapatkan bantuan modal karena tidak adanya bantuan modal dari pemerintah yang terkait dalam permasalahan Kelompok Usaha Merica Maju Jayahanya mengandalkan modal sendiri untuk mengembangkan usaha meraka seperti tempat tempat yang layak dan juga modal membeli alat-alat dan bahan-bahan yang dibutuhkan dalam mengelolah merica. Dari bantuan yang belumdiberikan, Kelompok Usaha Merica Maju Jaya masih belum cukup untuk mengembangkan usahanyadikarenakan belim adanya bantuan dari pemerintah.

\section{Terbatasnya Bahan Untuk Mengelolah Merica}

Bahan kadang susah untuk didapatkan, hal tersebut menjadikan Kelompok Usaha Merica Maju Jaya harus mendatangkan bahan dari luar daerah,itupun kalau bahannya ada di daerah tersebut dimana harga bahan dari luar daerah lebih mahal. Seperti pupuk yang bagus juga harganya mahal begitu pula sebaliknya. Dan juga permasalahan yang sampai saat ini belum mendapatkan jalan keluar yaitu menemukan pupuk yang ampuh untuk memusnahkan ulat-ulat batang yang meresahkan karena adanya ulat tersebut membuat beberapa pohon merica membusuk dan mati karena di serang oleh hama ulat batang tersebut.

\section{Hubungan Kurang Baik Antaranggota Sehingga Menimbulkan Rasa Bosan}

Hubungan kurang baik bisa membuat kelompokmenjadi tidak kompak yang menyebabkan anggota menjadi tidak betahmengikuti kegiatan di Kelompok Usaha Merica Maju Jaya. Disamping itu, merasa bosan dengan aktivitas yang dilakukan juga sebagaipenyebab anggota keluar dan mencari pekerjaan yang lainnya.

\section{KESIMPULAN}

1. Upaya Peningkatan Kesejahteraan Sosial Petani Melalaui Kelompok Usaha Merica Desa Mowila Kecamatan Mowila Kabuputen Konawe Selatan yakini:

a. Memberikan pemahaman dan kesempatan kerja bagi masyarakat yang kurang beruntung di dunia kerja bahwa anggota kelompok dibekali mengani cara bercocok tanam yang baik mengenai merica agar memiliki hasil yang banyak, selain itu juga dengan bergabung dengan anggota kelompok bisa memliki pekerjaan sampingan untuk menambah penghasilan keluarga.

b. Mendorong dan membimbing petani agar mampu bekerja sama di bidang usaha secara berkelompok bahwa petani saling memberi motivasi dan pemahan agar pertanian merica yang mereka lakukan bisa memliki penghasilan yang banyak.

2. Faktor pendukung dan faktor penghambat kelompok usaha merica maju jaya Desa Mowila Kecamatan Mowila Kabuputen konawe selatan.

a. Faktor Pendukung yakini (1) Kerjasama, bahwa sesama anggota kelompok saling bekerjasama dalam hal pertanian merica. (2) Motivasi, bahwa ketua kelompok selalu memberikan motivasi 
kepada anggota kelompok agar bekerja serius untuk menanam merica agar pertanian mereka bisa mengahsilkan ahsol yang memuaskan. (3) Bersifat transparan dan kepercayaan antara pihak-pihak terkait bahwa sesama anggaota kelompok saling bertukar pendapat mengenai yang terbaik untuk keberlangsungan kelompok mereka dan saling menjaga kepercayaan antara satu dan yang lainya.

Faktor Penghambat yakni (1) Kurangnya Bantuan Modal bahwa kelompok ini tidak memliki asupan modal dari pemerintah dan mereka lebih mengandalkan modal sendiri yang dikumpul setiap pekanya. terbatasnya bahan untuk mengelolah merica bahwa dalam hal mendapatkan kebutuhan untuk keperluan petanian merica itu sangat terbatas seperti mendaptkan racun serangga. (3) Hubungan kurang baik antar anggota sehingga menimbulkan rasa bosan bahwa sesama anggota kelompok terkadang berselisih faham dan pernah diantara anggota kelompok yang keluar dari kemlompok.

\section{SARAN}

Setelah mengemukakan beberapa kesimpulan, maka dalam uraian tersebut akan dikemukakan saran sebagai harapan yang ingin dicapai dalam penelitian ini berikut ;

1. Anggota Kelompok Usaha Merica Maju Jaya harusmempertahankan usaha mereka yang telah ada dan lebih meningkatkan kualitas usaha dengan cara lebih baik dari sebelumnya.

2. Pelindung dari Kelompok Usaha Merica Maju Jaya dalam hal ini Kepala Kecamatan Mowila harus meningkatkan bentuk kerja sama dalam hal pengelolahan dan pemasaran agar Kelompok Usaha Maju Jaya terus maju.

Ketua Kelompok Usaha Merica Maju Jaya hendaknya menjalinkerjasama dengan pihak lain yang berkaitan dengan program kegiatan, selaindapat memperluas jaringan dan mensosialisasikan program, hal itu juga dapat digunakan untuk mencari dana tambahan untuk membantu merealisasikan program yang direncanakan.

\section{DAFTAR PUSTAKA}

Abbas 2006, S., R. Wiratmadja, dan E Pasandaran. 2006. Sekolah Lapangan Sebagai Instrumen Penyuluhan Pertanian. Jakarta. Yayasan Padi Indonesia.

Adi, Isbandi Rukminto, 2013 Kesejahteraan Sosial, Jakarta, Rajawali Press.

Adi Fahruddin, 2012 Pengantar Kesejahteraan Sosial. Bandung .PT Refika Aditama.

Aditama, 2010.Memberdayakan Masyarakat Memberdayakan Rakyat. Bandung: Pt Refika.

Afrizal, Mohamad. (2014). Pemberdayaan Masyarakat melalui Wirausaha Kerajinan Panel Bambu di Koperasi Kasongan Usaha Bersama (KUB) Kalipucang, Bangunjiwo, Kasihan, Bantul.Universitas Negeri Yogyakarta.

Arsyad, Lincolin, 1992, Ekonomi Pembangunan, Edisi 2, Bagian Penerbitan Sekolah Tinggi Ekonomi YKPN, Yogyakarta.

Barnawi, Mohammad Arifin, 2012. School preneur ship: Membangkitkan Jiwa \& Sikap Kewirausahaan Siswa, Jogjakarta :Ar-Ruzz Media.

Basrowi, 2011. Kewirausahaan Untuk Perguruan Tinggi, Bogor :Penerbit Ghalia Indonesia.

Eman Suherman, 2008. Desain Pembelajaran Kewirausahaan, Bandung: Alfabeta.

Ginandjar Kartasasmitha, 1996. Pembangunan Untuk Rakyat: Memadukan Pertumbuhan dan Pemerataan, Jakarta: PT Pusaka Cisendo.

Isbandi Rukminto Adi, 2008. Intervensi Komunitas Pengembangan Masyarakat Sebagai Upaya Pemberdayaan Masyarakat, Jakarta: PT Grafindo Persada. 
Khatib Kayo, Pahlawan. (2008). Kube Sebagai Wahana Intervensi Komunitas Dalam Praktek Pekerjaan Sosial. Padang: BBPPKS

Kasmir, 2013. Kewirausahaan-Edisis Revisi, Jakarta: PT Raja grafindo Persada.

Mardikanto, Totok. 1993. Penyuluhan Pembangunan Pertanian. Surakarta: UNSPress.

Perry, Martin, 2002 Mengembangkan Usaha Kecil, Jakarta: PT Raja grafindo Persada.

Prayitno Hadi. 1998. Pembangunan Ekonomi Pedesaan, Yogyakarta: BPFE.

Soetriono, dkk. 2006. Pengantar Ilmu Pertanian Agraris, Agrobisnis, dan Industri. Malang: Bayu media Publishing.

Suhardiyono, L. 1992. Petunjuk Bagi Penyuluh Pertanian. Jakarta: Erlangga.

Suharto, Edi. 2006. Membangun Masyarakat Memberdayakan Rakyat, Bandung: PT Refika.

Yuyus 2010. Suryanadan Kartib Bayu, Kewirausahaan: Pendekatan Karakteristik Wirausahawan Sukses, Jakarta: Kencana Prenada Media Group.

Zubaedi, 2007. Wacana Pembangun Alternatif: Ragam Prespektif Pembangunan dan Pemberdayaan Masyarakat. Jakarta: ArRuzz Media. 